\title{
Differences in types of artificial cranial deformation are related to differences in frequencies of cranial and oral health markers in pre-Columbian skulls from Peru
}

\author{
Diferenças nos tipos de deformação craniana artificial estão relacionadas \\ a diferenças nas frequências de marcadores de saúde craniana e \\ oral em crânios pré-colombianos do Peru
}

\author{
Mercedes Okumura \\ Universidade de São Paulo. Museu de Arqueologia e Etnologia. São Paulo, São Paulo, Brasil
}

\begin{abstract}
Artificial cranial deformation is a cultural practice that modifies the shape of the skull during the early infancy. It is not related to rites of passage, but to different social status in a group. Therefore, the deformed cranium is an expression of individual affirmation and affiliation to a given social group. Osteological material from Pasamayo (AD 1200-1450), a cemetery in central coast of Peru, was analyzed to test whether individuals presenting different types of cranial deformation (interpreted as a sign of different social status) present differences in health status. Three types of cranial deformation were observed and five osteological markers (cribra orbitalia, cranial trauma, antemortem tooth loss, dental caries, and periodontal cavities) related to health status were analyzed in 78 crania. No significant differences were found in terms of these osteological markers among females in relation to the different types of cranial deformation. However, males presenting occipital deformation had significantly less caries and periodontal cavities than the others. Moreover, males presenting fronto-lambdoid deformation had more antemortem tooth loss than the other males. Therefore, although different types of cranial deformation can be potentially associated to distinct social status, differences in health status could only be observed in the male sample.
\end{abstract}

Keywords: Bioanthropology. Palaeopathology. Archaeology. Pasamayo.

Resumo: A deformação craniana intencional é uma prática cultural que modifica a forma do crânio durante o início da infância, não sendo relacionada a ritos de passagem, mas a diferentes stati sociais dentro de um grupo. Portanto, o crânio deformado é uma expressão de afirmação individual e filiação a um determinado grupo social. Material osteológico de Pasamayo (1200-1450 AD), um cemitério na costa central do Peru, foi analisado para testar se indivíduos portadores de diferentes tipos de deformação craniana (interpretados como sinais de status social diferenciado) apresentavam diferenças em termos de saúde. Foram observados três tipos de deformação craniana e analisados cinco marcadores relacionados à saúde (cribra orbitalia, trauma craniano, perda de dentes antemortem, cáries e cavidades periodontais) em 78 crânios. Não foram encontradas diferenças significativas nesses marcadores entre as mulheres em relação aos diferentes tipos de deformação craniana. No entanto, os homens com deformação occipital apresentaram menor frequência de cáries e cavidades periodontais em comparação aos outros. Além disso, homens que apresentavam deformação fronto-lambdoide tiveram maior perda de dentes antemortem quando comparados aos outros. Portanto, embora diferentes tipos de deformação craniana possam ser potencialmente associados a condições sociais distintas, diferenças em termos de saúde foram observadas apenas na amostra do sexo masculino.

Palavras-chave: Bioantropologia. Paleopatologia. Arqueologia. Pasamayo.

OKUMURA, Mercedes. Differences in types of artificial cranial deformation are related to differences in frequencies of cranial and oral health markers in pre-Columbian skulls from Peru. Boletim do Museu Paraense Emílio Goeldi. Ciências Humanas, v. 9, n. 1, p. 15-26, jan.-abr. 2014.

Autor para correspondência: Mercedes Okumura. Av. Professor Almeida Prado, 1466. São Paulo, SP, Brasil. CEP 05508-070 (okumuram@usp.br). Recebido em 21/03/2013

Aprovado em 11/12/2013

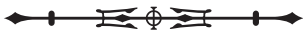




\section{INTRODUCTION}

The term 'cultural cranial deformation' is used to describe practices that alter the shape of the cranium in infancy and early childhood. This is a very ancient practice, with evidence of cranial deformation having been found in Neanderthals (Trinkaus, 1982) and in Australians in the PleistoceneHolocene transition (Antón and Weinstein, 1999, but see Durband, 2011 for a different view). It can be an intentional practice (to produce a specific shape), or can be the byproduct of other behaviour, such as the use of a board or band to swaddle the infant to the cradle (Brothwell, 1981, p. 48). In the first case, there is a clear intention of differentiate the deformed individuals from the non-deformed, which can be related to an idea of group identity (Munizaga, 1992; Gerszten, 1993; Torres-Rouff, 2002; Blom, 2005; Romero-Vargas et al., 2010). However, regardless the non-intentional character, it is not possible to affirm whether non-intentional cranial deformations carry any social meaning (Torres-Rouff, 2003). Cranial deformations have been seemed by anthropologists as a cultural characteristic "that marks territory or social boundaries, reaffirms ethnicity, and maintains and strengthens exchange networks" (Gerszten, 1993, p. 87). According to Ayer et al. (2010, p. 1), "evidence suggests that physical or artistic manipulation of skulls was undertaken not just to reinforce social distinctions, but also to entrench political power". Therefore, it can serve as a permanent symbol of within-group solidarity and of cultural differences between groups (Torres-Rouff, 2002).

During the first years of life, the bones of the skull are quite malleable, and therefore the cranial deformation has to be performed in this early period. Unlike other types of body modification, this practice is not associated to any rites of passage and therefore becomes a constant and fundamental symbol of social identity (Torres-Rouff, 2003). Obviously, deformed crania were considered as a sign of beauty and the more an individual was deformed, more beautiful he/she was considered (Blackwood and Danby, 1955; Munizaga, 1987; O'Loughlin, 2004). Torres-Rouff and Yablonsky (2005) say that the interaction between society and body is critical to understand the social context of the body modifications and therefore, cranial deformations are a strong affirmation about the affiliation of an individual to a group. For example, in the Andean South America, cranial deformation was used to delimit social boundaries both within and among groups (Romero-Vargas et al., 2010).

Hoshower et al. (1995) reported that the Inca used cranial deformation to mark the elite and as a way of distinguishing themselves from the citizens of their empire (see also Romero-Vargas et al., 2010). In the same way, Incas homogenised the type of deformation in each group to better identify the different members of their empire (de las Casas, 1892, p. 594-595 apud Torres-Rouff and Yablonsky, 2005). For Torres-Rouff and Yablonsky (2005), this example offers some documentation that can be used in order to understand what can be found in the archaeological record of other groups.

Although the reasons for the adoption of the practice of cranial deformation vary from group to group (Dingwall, 1931; Garrett, 1988), it is well known that most of the groups considered this practice as a sign of high status, and frequently slaves were not allowed to practice it. For example, Nagaoka et al. (2012) describe the skeletal remains of a female individual found in a cemetery from the northern highlands of Peru dated from the Formative period (2500-1 BC). The individual presented artificial cranial deformation and a high stature, being buried with a pair of gold earplugs, a pair of gold earrings, and shell objects including a necklace and leg ornaments. The characteristics of the burial were interpreted as a possible evidence for social stratification in the Formative period.

Although O'Loughlin (2004) says that non-deformed individuals, in a group where cranial deformation is valued, are assign as belonging to the lower classes (and maybe presenting different genetic and/or nutritional background), the author does not discuss the meaning of different types of cranial deformation within the same group. For TorresRouff (2004), in some cases, the type of cranial deformation was a marker of different groups within the same society. 
She cites the Oruro (in Bolivia), in which the types of cranial deformation were used to differentiate social classes: high class individuals had tabular erect heads, middle class had tabular oblique heads, and the rest of them had ring-shaped head. Romero-Vargas et al. (2010) describes a similar case during the Classic period of Mayan culture: the general population could only perform erect deformations. Oblique deformations were allowed only if such individuals were destined to a high-status position (governors, priests or warriors). Therefore, if the cranial deformation can be used as a sign of social status, it must be possible to access the social status of an individual through this osteological feature and compare the health status among them. Many studies in contemporary societies say that there is a positive correlation between social status and health status, especially in terms of oral health (Antoft et al., 1999; Irigoyen et al., 1999; Donaldson et al., 2008; Oliveira et al., 2008; Pieper et al., 2012; among others). Although these studies are based on western societies, this positive relation can be found also in other groups. For example, Walker and Hewlett (1990) observed that leaders of a community of pygmies in Africa presented better oral health than the rest of the people. In the Mayan society, elite males presented less carious lesions than females from the same social class and males and females from the lower classes. Clearly, low social status individuals presented higher frequencies of antemortem tooth loss than high status individuals (Cucina and Tiesler, 2003).

Models can be evaluated through an analysis of osteological markers associated to health conditions and the types of cranial deformation. This study is based on the idea that the several types of cranial deformation can be used as a good evidence of differential social status and that some osteological markers can be fair indicators of health status. Through the study of skulls from the Peruvian cemetery of Pasamayo, this article aims to test whether individuals presenting different types of cranial deformation show important differences in the frequencies of cranial and oral health markers.

\section{MATERIAL AND METHODS}

The bioarchaeological record in South America is characterized by the high frequency of individuals presenting a great variety of cranial deformation (Imbelloni, 1933). The crania studied are currently housed at the Duckworth Laboratory of the University of Cambridge. The material was collected by Thomas J. Hutchinson in 1871 (Hutchinson, 1873) and acquired later by Sir G. M. Humphry. Pasamayo is a huge pre-Columbian cemetery in the central Peruvian coast dated from AD 1200-1450. The associated pottery is related to the Late Chancay period (Chancay is a small regional polity that arose on the central coast of Peru during the Late Intermediate period, best known for elaborate ceramics and fine gauze work; Strong et al., 1943). Hutchinson (1873, p. 90; 1875) described this cemetery. A huge amount of human skeletal remains was found on the surface, and although some excavations were made, it is not possible to know which material was excavated and which was collected from the surface (Fairgrieve, 1990).

Crania from 78 adult individuals (47 males and 31 females) were analyzed (Table 1). All individuals were sexed based on the cranial morphology (Buikstra and Ubelaker, 1994), once Cocilovo (1975) demonstrated that head shaping does not greatly affect sexually dimorphic cranial features.

Occlusal dental wear is a process caused mainly by attrition, abrasion, and erosion (Kaidonis et al., 1988). According to Watson (2008), food consistency, as well as foreign abrasives, would be the most important factors to influence the overall rate of the wear of the occlusal tooth surface. Occlusal dental wear of the first and second left molars was analysed according to Molnar (1971), taken into account the occlusal surface as a whole. The method suggested by Smith (1972) was utilised. Smith (1972) proposed that the wear coefficient calculated between the first and the second molar (from the same side) could be used as an index independent of age because the molars erupt on a schedule that is relatively independent of environmental conditions. This approach is very valuable when the sample does not present enough juvenile 
Table 1. Number of individuals (I) and units (U) analysed.

\begin{tabular}{|c|c|c|c|c|c|}
\hline & & \multicolumn{3}{|c|}{ Cranial deformation } & \multirow{2}{*}{ Total } \\
\hline & & Occipital & Lambdoid & Fronto-lambdoid & \\
\hline \multirow{6}{*}{ Male } & Cribra and trauma (I) & 18 & 26 & 3 & 47 \\
\hline & Dental wear (I) & 2 & 6 & 1 & 9 \\
\hline & Teeth $(\cup)$ & 37 & 72 & 10 & 119 \\
\hline & Alveoli (U) & 246 & 411 & 48 & 705 \\
\hline & Teeth (I) & 18 & 26 & 3 & 47 \\
\hline & Alveoli (I) & 18 & 26 & 3 & 47 \\
\hline \multirow{6}{*}{ Female } & Cribra and trauma (I) & 5 & 23 & 3 & 31 \\
\hline & Dental wear (I) & 4 & 5 & 2 & 11 \\
\hline & Teeth $(U)$ & 19 & 53 & 14 & 86 \\
\hline & Alveoli (U) & 80 & 366 & 48 & 494 \\
\hline & Teeth (I) & 5 & 23 & 3 & 31 \\
\hline & Alveoli (I) & 5 & 23 & 3 & 31 \\
\hline
\end{tabular}

individuals from where a specific dental wear rate can be obtained (Miles, 2001).

The types of cranial deformation were classified according to O'Loughlin (2004) and five osteological markers related to general health (cribra orbitalia, cranial trauma, antemortem tooth loss, caries and periodontal cavities) were analyzed.

Macroscopically, cribra orbitalia can range from small isolated apertures spread over the roof of the orbit to confluent openings that result in the formation of trabecular bone (Brothwell, 1981, p. 165). These modifications related to the hyperplasia of the diploë are a response to iron deficiency anaemia caused by undernutrition, intestinal parasites, and infectious diseases, among other factors (Stuart-Macadam, 1992, but see Rothschild, 2012, for a different view). Cribra orbitalia was considered present when there was a cluster of fine foramina covering a small area, as well as when a substantial area $\left(>1 \mathrm{~cm}^{2}\right)$ was covered by small and/ or larger foramina with a tendency to cluster together.

Traumas, especially fractures, are a valuable osteological marker that can help to reconstruct two different aspects of behaviour: daily accidents and social tension. Fractures happen when the bone is deformed excessively, beyond its tolerance. The interpretation of the mechanisms of cranial injuries is based on a variety of bone features related to the pattern of fracture lines and the presence of deformation (Kaufman et al., 1997; Lovell, 1997). Stress fractures, as well as fractures secondary to pathological processes are very uncommon in the cranium. There are several classifications of fractures in the literature, most of them based on the mechanism of the lesion. We have utilized the descriptions of Grauer and Roberts (1996) that divided cranial fractures as resulting from blunt force/ low impact speed (producing depression or linear fractures) and acute force (producing penetrating fractures), although these categories are not mutually exclusive. With this data, it is possible to speculate about the social and environmental reasons for the frequency of trauma in a certain population.

Antemortem tooth loss (AMTL) is strongly related to periodontal disease or to the exposure of the pulpar chamber of the teeth (caused by dental wear or caries), because these factors contribute to the alveolar inflammatory process, resulting in the expulsion of the teeth (Hillson, 1996). Antemortem tooth loss was recorded in 
cases in which complete alveolar resorption was visible or in which substantial evidence of the process was observed.

Caries are characterized by the progressive demineralization of the hard tissue of teeth by the acid resulting from fermentation process of bacteria. Although the aetiology of caries is still not fully understood, some factors can influence the development of caries in some individuals, such as oral environment, bacterial flora composition, and diet (Buikstra and Ubelaker, 1994; Hillson, 1996; Lukacs, 1996). Caries were observed macroscopically on all permanent teeth and were registered as present when the cavity was at least $2 \mathrm{~mm}$ wide and had reached the dentine (Schultz, 1988). Such method excluded the possibility of confusing enamel pits with early stages of caries (Cucina and Tiesler, 2003).

Quite common in prehistoric human remains, the presence of a tooth presenting an open chamber associated with bone cavities is usually described as 'abscess'. According to Hillson (2005, p. 313), most of these cavities probably are granulomata or cysts, but their differential diagnosis in skeletal remains is quite difficult. Usually such cavities are related to the exposition of the alveolus to pathogenic external agents, through periodontal diseases or the exposure of pulpar chamber. Therefore, they are related to the frequency of caries or the severity of occlusal wear (Lukacs, 1996). In this study, we will use the term 'periodontal cavities' to describe abscesses, granulomata, and cysts. Periodontal cavities were considered present when a cavity was exposed through a window in the buccal or lingual wall of the alveolar process (Hillson, 2005, p. 313).

Analyses were carried out using the individual as the unit of analysis. In the case of oral markers (antemortem tooth loss, caries, and periodontal cavities), in addition to analysis by individual (for example, the frequency of individual presenting at least one carious tooth), analyses were also made considering tooth or alveolus as the unit of analysis (for example, the frequency of carious teeth in relation to the total number of teeth available).

Fisher's Exact Test was used in order to examine the kind of association (contingency) between the variables because, in many cases, the very low expected values would imply in unreliable results of the Chi Square Test (Drennan, 2010, p. 192).

\section{RESULTS}

All analysed individuals presented some kind of cranial deformation, and no significant differences in terms of sex were found. The kinds of deformation found were occipital, lambdoid and one not described by O'Loughlin (2004), fronto-lambdoid (Figure 1 and Table 2).

No important differences could be found in terms of relative age in the sample analyzed (Figure 2), because the dental wear coefficients were very similar. Although there is a peak in the dental wear coefficient observed in male sample with fronto-lambdoid deformation, this value is represented by just one individual.

Significant differences between sexes included a higher frequency of cranial trauma in females ( $p=$ 0.0053), while male presented higher frequencies of antemortem tooth loss per unit $(p<0.0001)$ and per

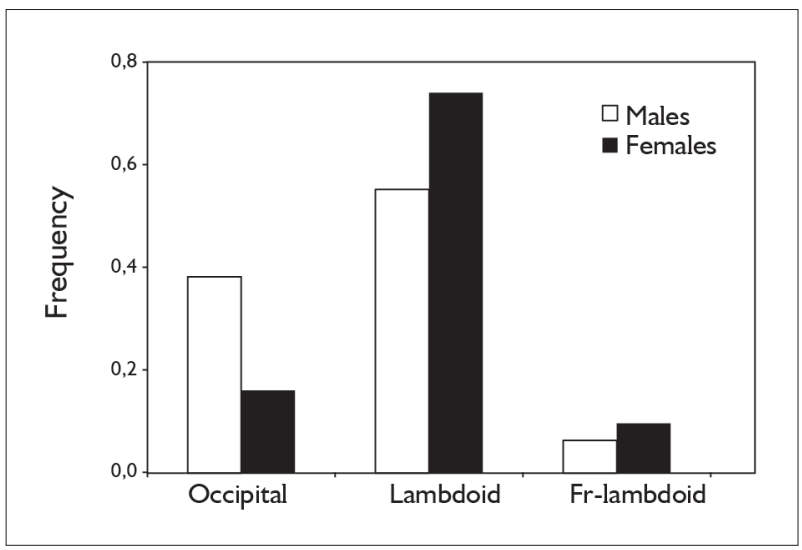

Figure 1. Frequencies of types of cranial deformation observed according to sex. Fr-lambdoid $=$ fronto-lambdoid.

Table 2. Type of cranial deformation observed in the male and female samples (observed/total number).

\begin{tabular}{c|c|c|c}
\hline & Occipital & Lambdoid & Fronto-lambdoid \\
\hline Males & $18 / 47$ & $25 / 47$ & $3 / 47$ \\
\hline Females & $5 / 31$ & $23 / 31$ & $3 / 31$ \\
\hline
\end{tabular}


individual $(p=0.0010)$, and periodontal cavities per alveolus ( $p=0.0558)$ (Figure 3 and Table 3$)$.

Cranial traumas observed in five females were small circular/oval depressions on the left parietal, next to the insertion of the temporal muscle, varying from $24 \times 14 \mathrm{~mm}$ to $10 \times 7 \mathrm{~mm}$ (this kind of trauma was also observed in a juvenile individual). All traumas were inactive at the time of death, except in one individual which also presented a perimortem fracture on the left parietal. The other two females presented a large healed depression $(39 \times 25 \mathrm{~mm})$ on the right parietal, next to the meeting between the coronary suture and the sagital suture and the other had a small punctuated fracture on the sagital suture $(10 \times 6 \mathrm{~mm})$, next to the occipital bone. Traumas observed in the male sample included two individuals with traumatic lesions on the face: one of them had an active lesion on the right zygomatic bone (next to the meeting between the zygomatic and the frontal bone) and the other, besides a healed fracture on the right maxilla, had also a depression almost completely healed on the left side of the frontal $(19 \times 9 \mathrm{~mm})$. Another individual presented a punctuated healed fracture on the right parietal $(11 \times 9 \mathrm{~mm})$.

It was not possible to observe any significant difference in the frequencies of osteological markers of women in terms of different types of cranial deformation (Figure 4 and Table 4).

In the male sample, individuals presenting occipital deformation had less caries per teeth in comparison to the other groups ( $p=0.041$ in relation to the fronto-lambdoid group and $p=0.0151$ in relation to the lambdoid group). Individuals presenting occipital deformation had less periodontal cavities per alveolus when compared to the ones presenting fronto-lambdoid deformation $(p=0.085)$ and less caries per individual than the ones with lambdoid

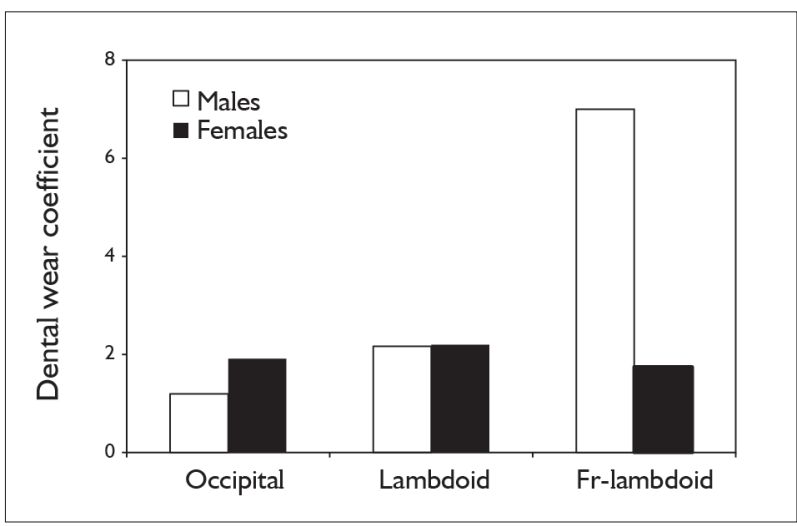

Figure 2. Dental wear coefficient observed for both sexes according to the type of cranial deformation. Fr-lambdoid = fronto-lambdoid.

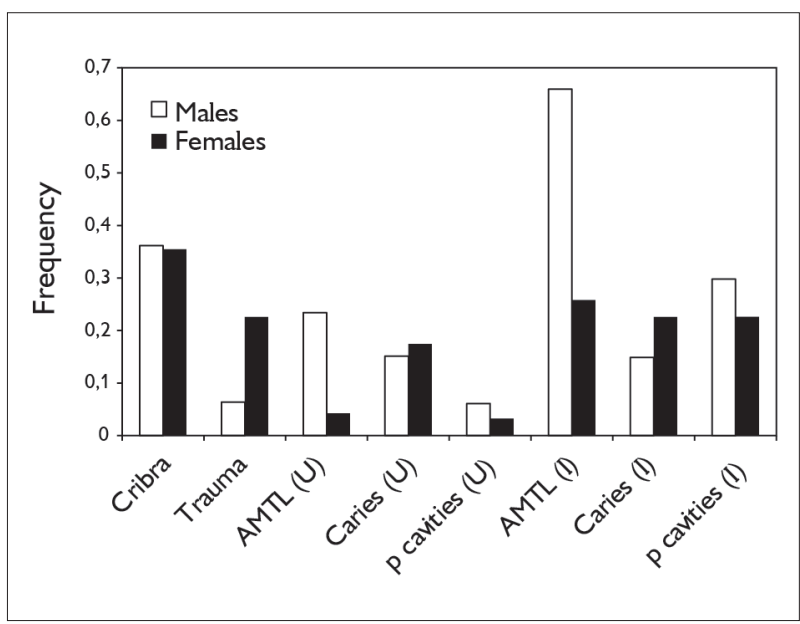

Figure 3. Frequencies of osteological markers according to sex. $U=$ frequency per unit (tooth or alveolus); I = frequency per individual; p cavities $=$ periodontal cavities

deformation $(p=0.0668)$. Fronto-lambdoid deformed individuals presented a significant higher frequency of antemortem tooth loss per alveolus than the others ( $p=$ 0.0638 in relation to the occipital group and $p=0.0132$ in relation to the lambdoid group) (Figure 5 and Table 5).

Table 3. Pathologies observed in the male and female samples (observed/total number) according to the number of individuals and the number of units. I = number of individuals; $U=$ number of units; $p$ cavities = periodontal cavities.

\begin{tabular}{c|c|c|c|c|c|c|c|c}
\hline & Cribra (I) & Trauma (I) & AMTL (U) & Caries (U) & P cavities (U) & AMTL (I) & Caries (I) & P cavities (I) \\
\hline Male & $17 / 47$ & $3 / 47$ & $165 / 705$ & $18 / 119$ & $43 / 705$ & $31 / 47$ & $7 / 47$ & $14 / 47$ \\
\hline Female & $11 / 31$ & $7 / 31$ & $21 / 494$ & $15 / 86$ & $16 / 494$ & $8 / 31$ & $7 / 31$ & $7 / 31$ \\
\hline
\end{tabular}

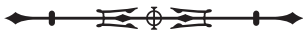




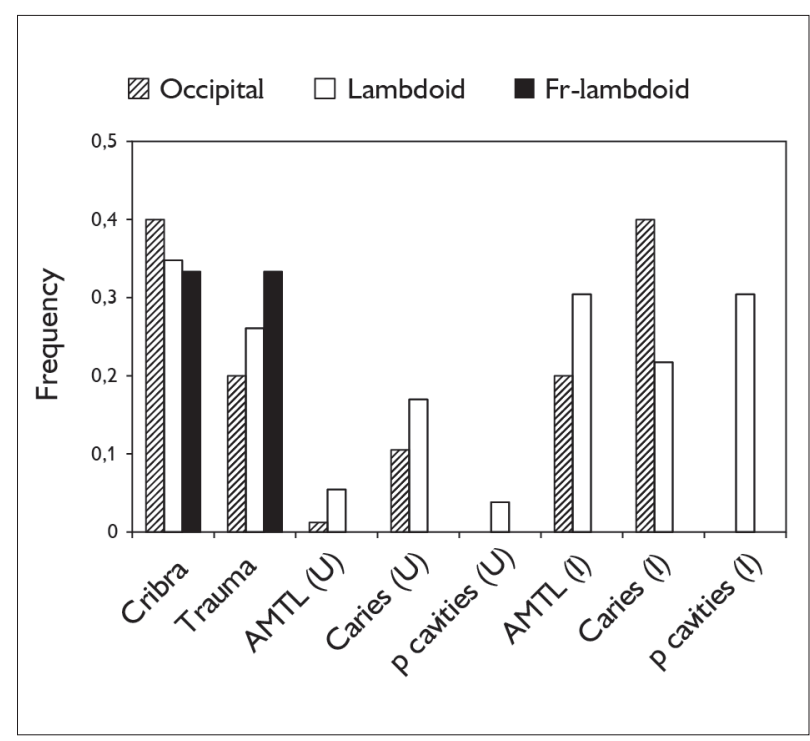

Figure 4. Frequencies of osteological markers according to the type of cranial deformation (females only). $U=$ frequency per unit (tooth or alveolus); I = frequency per individual; $p$ cavities = periodontal cavities; Fr-lambdoid $=$ fronto-lambdoid.

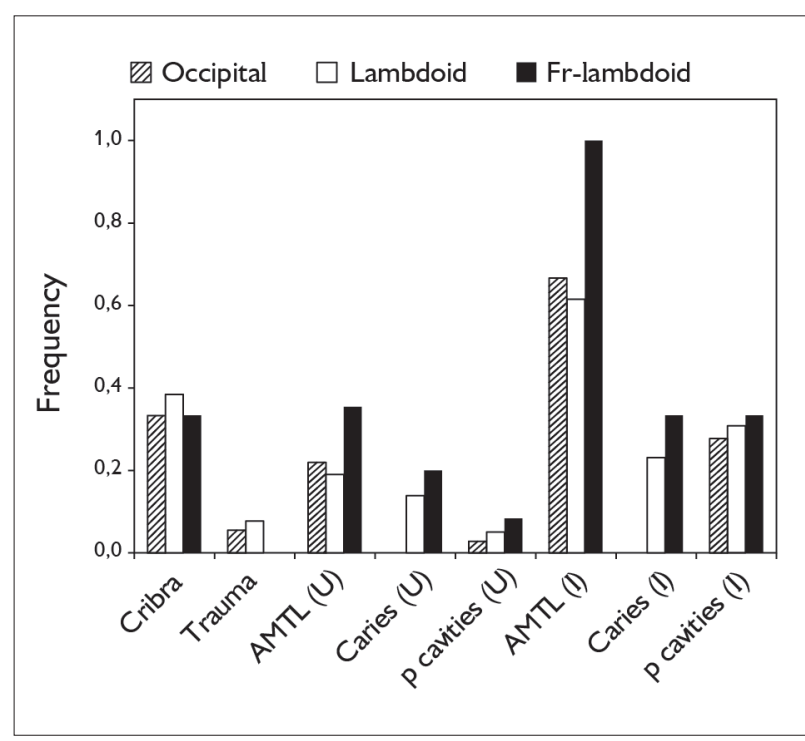

Figure 5. Frequencies of osteological markers according to the type of cranial deformation (males only). $U=$ frequency per unit (tooth or alveolus); I = frequency per individual; $\mathrm{p}$ cavities = periodontal cavities; Fr-lambdoid $=$ fronto-lambdoid

Table 4. Pathologies observed in the female sample (observed/total number) according to the type of cranial deformation. I = number of individuals; $U=$ number of units; $p$ cavities = periodontal cavities; Fr-lambdoid = fronto-lambdoid.

\begin{tabular}{c|c|c|c|c|c|c|c|c}
\hline & Cribra (I) & Trauma (I) & AMTL (U) & Caries (U) & p cavities (U) & AMTL (I) & Caries (I) & p cavities (I) \\
\hline Occipital & $2 / 5$ & $1 / 5$ & $1 / 80$ & $2 / 19$ & $0 / 80$ & $1 / 5$ & $2 / 5$ & $0 / 5$ \\
\hline Lambdoid & $8 / 23$ & $6 / 23$ & $20 / 366$ & $9 / 53$ & $14 / 366$ & $7 / 23$ & $5 / 23$ & $7 / 23$ \\
\hline Fr-lambdoid & $1 / 3$ & $1 / 3$ & $0 / 48$ & $0 / 14$ & $0 / 48$ & $0 / 3$ & $0 / 3$ & $0 / 3$ \\
\hline
\end{tabular}

Table 5. Pathologies observed in the male sample (observed/total number) according to the type of cranial deformation. I = number of individuals; $U=$ number of units; $p$ cavities = periodontal cavities; Fr-lambdoid = fronto-lambdoid.

\begin{tabular}{c|c|c|c|c|c|c|c|c}
\hline Total & Cribra (I) & Trauma (I) & AMTL (U) & Caries (U) & p cavities (U) & AMTL (I) & Caries (I) & p cavities (I) \\
\hline Occipital & $6 / 18$ & $1 / 18$ & $54 / 246$ & $0 / 37$ & $7 / 246$ & $12 / 18$ & $0 / 18$ & $5 / 18$ \\
\hline Lambdoid & $10 / 26$ & $2 / 26$ & $78 / 411$ & $10 / 72$ & $20 / 396$ & $16 / 26$ & $6 / 26$ & $8 / 26$ \\
\hline Fr-lambdoid & $1 / 3$ & $0 / 3$ & $17 / 48$ & $2 / 10$ & $4 / 48$ & $3 / 3$ & $1 / 3$ & $1 / 3$ \\
\hline
\end{tabular}

\section{DISCUSSION}

The results show that all individuals collected in Pasamayo presented some type of cranial deformation, including a type not described by O'Loughlin (2004), the frontolambdoid deformation. Both sexes were equally affected by this practice, and no differences in the frequency or the type of deformation were found. The absence of sexual differences in the frequency of this practice was also observed in other groups (Gerszten, 1993; Tiesler, 1999) and it can be suggested that this modification was not related to the reinforcement of gender differences (Torres-Rouff, 2002).

Cranial traumas in past populations can be interpreted as an evidence of interpersonal violence (Walker, 1989; Jurmain, 1991; Stodder and Martin, 1992; Walker et al., 1997). 
An unexpected higher frequency of cranial trauma was found in the female sample when compared to the male one. This is not in agreement with most of the studies that show a higher frequency of traumas in males, due to warfare and hunting activities (Slaus et al., 2004). For example, Standen and Arriaza (2000) observed that the frequency of cranial traumas in Chilean skeletons from Chinchorro was three times more frequent in males than females. Significant differences were also found in La Real, an archaeological site associated to the Wari Empire, in Andean Peru (Tung, 2007) and in Pachacamac, an Andean religious and pilgrimage centre (Torres-Rouff, 2003). Other groups did not present significant differences between sexes in terms of cranial fractures (Keenleyside, 1998; Robb et al., 2001; Djurić et al., 2006; Judd, 2006; Tung, 2007) or traumas in general (Milner et al., 1991; Slaus et al., 2004; Okumura and Eggers, 2005; Paine et al., 2007). On the other hand, Torres-Rouff and Costa Junqueira (2006) observed a higher frequency of cranial traumas in females than in males from San Pedro de Atacama between 200 BC-AD 600, but not before this period. The authors proposed that the character of preColumbian warfare was different from the one observed in western contemporary societies, where groups of men unite and face each other to fight. It is also possible that women also had some participation in warfare, resulting in a higher frequency of lesions. Alvrus (1999) proposed that traumas found in the female sample from Nubia could be a result of raids. Most of cranial trauma observed in females was healed compressed fractures, which according to Roberts and Manchester (1995) is probably the most common type of cranial fracture that can be found in archaeological contexts. On the other hand, the facial fractures found in males from Pasamayo, and especially the punctuated fracture observed in one of them strongly suggests violent episodes. Walker (1989) says that facial fractures (like the ones observed in our sample) are a strong indicator of interpersonal violence, as well as perimortem, multiple and parry fractures (Keenleyside, 1998), which could not be observed in our sample because there are no postcranial bones available.
The non-lethal nature of the observed trauma suggests the possibility of some form of hostility that could emphasize the lesion, and not the death (Walker, 1989). Torres-Rouff and Costa Junqueira (2006) observed that the lesions found in skeletons from San Pedro de Atacama reveal face to face confrontations similar to the ones reported by Tung (2007) as a ritual violence observed in southern Peru. Contemporary reports describe a Peruvian ritual battle named Tinku, which has the objective of causing injury to the opponent (Orlove, 1994, p. 133). Ritualized violence was proposed by Standen and Arriaza (2000) to explain the high frequencies of cranial traumas in Chinchorro cultures on coastal Chile. For Torres-Rouff and Costa Junqueira (2006), although comparative data can suggest that ritualized violence can be the causal factor of the pattern of trauma revealed in San Pedro de Atacama, it is not possible to rule out the possibility that individual conflicts, possibly related to land and resources could be responsible for these lesions. In fact, there is a relationship between the scarcity of resources and the occurrence of conflicts (Walker, 1989; Okumura and Eggers, 2005).

Males presented a worse condition in terms of oral health; the frequency of antemortem tooth loss (per alveolus and per individual) and periodontal cavities (per alveolus) was significantly higher than the frequencies found in women. The relative ages according to sex (Figure 2) show that there are no important differences in the relative ages between sexes (given by dental wear). Therefore, these differences in oral health can be due to differential access to cariogenic food, distinct susceptibilities to oral diseases, different physiological injuries or cultural behaviours that could influence oral health (Slaus, 2000).

The absence of significant differences among women presenting different cranial deformation can be explained in terms of a real absence of differences in their health status (see Sakashita et al., 1997 for a complete absence of differences in dental health and social status), or that, in this case, cranial deformation cannot be used as a proxy or marker to predict differences in health status. 
In the male sample, individuals bearing frontolambdoid deformation presented a significantly higher frequency of antemortem tooth loss per alveolus than the other individuals, which can be interpreted as a sign of very bad oral health in this group. The high frequency of antemortem tooth loss is usually the result of inflammatory processes due to dental caries and alveolar exposition caused by periodontal disease and/or exposition of the pulpar chamber caused by a high rate of dental wear (Hillson, 1996, 2005; Lukacs, 1996). Therefore, it is not unreasonable to suppose that individuals with fronto-lambdoid deformation presented the worst oral health (although only one of the markers was considered as significantly different). Furthermore, individuals with occipital deformation presented fewer caries per tooth when compared to the other groups, fewer periodontal cavities per alveolus when compared to individuals bearing fronto-lambdoid deformation, and fewer caries per individual when compared to lambdoid deformed individuals. Our results indicate that the occipital deformed group presented a better oral health status than the other groups, while the fronto-lambdoid deformed group presented the worst oral health status.

Although it is not possible to say that individuals presenting occipital deformation surely belong to the upper classes, it is well known that there is a positive correlation between health and social status in many prehistoric groups (Walker and Hewlett, 1990; Antoft et al., 1999; Irigoyen et al., 1999; Cucina and Tiesler, 2003), which can be indicative of this group occupying a more privileged social position than the others. It would not be unreasonable to suggest that the group bearing occipital deformation may be related to a higher social status in relation to the other analyzed groups. On the other hand, individuals presenting frontolambdoid deformation apparently did not enjoy the same status associated to occipital and lambdoid deformed groups.

\section{CONCLUSIONS}

Although different types of cranial deformation can potentially be related to different social status, it was possible to verify that these differences were found just on the male sample and for some of the osteological markers related to oral health. Our results show that males presenting fronto-lambdoid deformation presented a high frequency of antemortem tooth loss per alveolus, while males with occipital deformation presented a low frequency of caries per tooth and per individual, as well as a low frequency of periodontal cavities per alveolus when compared to the ones presenting fronto-lambdoid deformation. For this reason, it is possible to suggest that fronto-lambdoid deformed individuals may be related to a low social status, whereas individuals bearing occipital deformation may be associated to a high social status. Furthermore, males exhibit worse oral health in comparison to women, which can be related to differential access to cariogenic food or cultural behaviours that could be influencing these pathologies, among other factors. Still, is quite intriguing that women presented a higher frequency of cranial traumas than men, although it was beyond our scope to determine the motivation behind such high frequencies of interpersonal violence. Obviously, these results must be viewed cautiously, given the relatively small sample size.

\section{ACKNOWLEDGEMENTS}

I would like to thank the Associate Editor of Archaeology and the two anonymous reviewers whose useful comments helped to improve the original version of this article. I own responsibility for any mistakes that may remain.

\section{REFERENCES}

ALVRUS, Annalisa. Fracture patterns among the Nubians of Semna South, Sudanese Nubia. International Journal of Osteoarchaeology, v. 9, n. 6, p. 417-429, 1999.

ANTOFT, P.; RAMBUSCH, E.; ANTOFT, B.; CHRISTENSEN, $H$. W. Caries experience, dental health behavior and social status: three comparative surveys among Danish military recruits in 1972, 1982 and 1993. Community Dental Health, v. 16, n. 2, p. 80-84, 1999.

ANTÓN, Susan C.; WEINSTEIN, Karen J. Artificial cranial deformation and fossil Australians revisited. Journal of Human Evolution, v. 36, n. 2, p. 195-209, 1999. 
AYER, Amit; CAMPBELL, Alexander; APPELBOOM, Geoffrey; HWANG, Brian Y.; MCDOWELL, Michael; PIAZZA, Matthew; FELDSTEIN, Neil A.; ANDERSON, Richard C. E. The sociopolitical history and physiological underpinnings of skull deformation. Neurosurgical Focus, v. 29, n. 6, p. E1, 2010.

BLACKWOOD, Beatrice; DANBY, P. M. A study of artificial cranial deformation in New Britain. The Journal of the Royal Anthropological Institute of Great Britain and Ireland, v. 85, n. 1-2, p. 173-191, 1955.

BLOM, Deborah E. A bioarchaeological approach to Tiwanaku group dynamics. In: REYCRAFT, Richard (Org.). Us and them: archaeology and ethnicity in the Andes. Los Angeles: Cotsen Institute of Archaeology, 2005. p. 153-182.

BROTHWELL, Don R. Digging up bones. 3. ed. New York: Cornell University Press, 1981

BUIKSTRA, Jane E.; UBELAKER, Douglas $H$. Standards for data collection from human skeletal remains. Fayetteville: Arkansas Archeological Survey, 1994. (Research Series n. 44).

COCILOVO, José A. Estudio de dos factores que influencian en la morfología craneana en una colección andina: el sexo y la deformación artificial. Revista del Instituto de Antropología Tucumán, v. 2, p. 197-212, 1975.

CUCINA, Andrea; TIESLER, Vera. Dental caries and antemortem tooth loss in the Northern Peten Area, Mexico: a biocultural perspective on social status differences among the Classic Maya. American Journal of Physical Anthropology, v. 122, n. 1, p. 1-10, 2003.

DE LAS CASAS, Bartolomé. De las antiguas gentes del Perú Madrid: Manuel G. Hernandes, 1892.

DINGWALL, Eric John. Artificial cranial deformation: a contribution to the study of the ethnic mutilations. London: John Bale, Sons \& Danielsson, 1931.

DJURIĆ, Marija P.; ROBERTS, Charlotte A.; RAKOCEVIĆ, Zoran B.; DJONIĆ, Danijela D.; LESIĆ, Aleksandar R. Fractures in Late Medieval skeletal populations from Serbia. American Journal of Physical Anthropology, v. 130, n. 2, p. 167-178, 2006.

DONALDSON, A. N.; EVERITT, B.; NEWTON, T.; STEELE, J.; SHERRIFF, M.; BOWER, E. The effects of social class and dental attendance on oral health. Journal of Dental Research, v. 87, n. 1, p. 60-64, 2008.

DRENNAN, Robert D. Statistics for archaeologists: a common sense approach. New York: Springer, 2010. (Série Interdisciplinary Contributions to Archaeology).

DURBAND, Arthur C. Is there evidence for artificial cranial deformation at the Willandra lakes? Australian Archaeology, n. 73 , p. $62-64,2011$
FAIRGRIEVE, Scott I. Size of sella turcica and its relation to iron deficiency anemia: a prehistoric example. American Journal of Physical Anthropology, v. 83, n. 1, p. 111-121, 1990.

GARRETT, John. Status, the Warrior class, and artificial cranial deformation. In: BLAKELY, Robert (Ed.). The King site: continuity and contact in Sixteenth Century. Georgia: University of Georgia Press, 1988. p. 35-46.

GERSZTEN, Peter C. An investigation into the practice of cranial deformation among the pre-Columbian peoples of northern Chile. International Journal of Osteoarchaeology, n. 3, p. 87-98, 1993.

GRAUER, Anne; ROBERTS, Charlotte. Paleoepidemiology, healing, and possible treatment of trauma in the medieval cemetery population of St. Helen-on-the-Walls, York, England. American Journal of Physical Anthropology, v. 100, n. 4, p. 531-544, 1996.

HILLSON, Simon. Teeth. 2. ed. Cambridge: Cambridge University Press, 2005

HILLSON, Simon. Dental Anthropology. Cambridge: Cambridge University Press, 1996.

HOSHOWER, Lisa M.; BUIKSTRA, Jane E.; GOLDSTEIN, Paul S.; WEBSTER, Ann D. Artificial cranial deformation at the Omo M10 site: a Tiwanaku complex from the Moquegua Valley Peru. Latin American Antiquity, v. 6, n. 2, p. 145-164, 1995.

HUTCHINSON, Thomas ]. Explorations amongst ancient burial grounds, chiefly on the sea coast valleys of Peru. The Journal of the Anthropological Institute of Great Britain and Ireland, v. 4, p. 2-13, 1875.

HUTCHINSON, Thomas ]. Two years in Peru: with explorations of its antiquities. London: Sampson Low, Marston Low and Searle, 1873. v. 1-2

IMBELLONI, José. América, cuartel general de las deformaciones. In: CONGRESSO INTERNACIONAL DE AMERICANISTAS, 25., La Plata, 1933. Anais... La Plata: Universidad Nacional de La Plata, 1933. Tomo 1, p. 59-68.

IRIGOYEN, M. E.; MAUPOME, G.; MEJÍA, A. M. Caries experience and treatment needs in a 6- to 12-year-old urban population in relation to socio-economic status. Community Dental Health, v. 16, n. 4, p. 245-249, 1999.

JUDD, Margareth A. Continuity of interpersonal violence between Nubian communities. American Journal of Physical Anthropology, v. 131, n. 3, p. 324-333, 2006

JURMAIN, Robert. Paleoepidemiology of trauma in a prehistoric central California population. In: ORTNER, Donald; AUFDERHEIDE, Arthur (Eds.). Human paleopathology: current syntheses and future options. Washington: Smithsonian Institution Press, 1991. p. 241-248. 
KAIDONIS, J. A.; RICHARDS, L. C.; TOWNSEND, G. C.; TANSLEY, G. D. Wear of human enamel: a quantitative in vitro assessment. Journal of Dental Research, v. 77, n. 12, p. 19831990, 1988.

KAUFMAN, M. H.; WHITAKER, D.; MCTAVISH, J. Differential diagnosis of holes in the calvarium: application of modern clinical data to palaeopathology. Journal of Archaeological Science, v. 24, n. 3, p. 193-218, 1997.

KEENLEYSIDE, Anne. Skeletal evidence of health and disease in precontact Alaskan Eskimos and Aleuts. American Journal of Physical Anthropology, v. 107, n. 1, p. 51-70, 1998.

LOVELL, Nancy C. Traumaanalysis in paleopathology. American Journal of Physical Anthropology, v. 104, suplemento 25, p. 139-170, 1997.

LUKACS, John R. Sex differences in dental caries rates with the origin of agriculture in South Asia. Current Anthropology, v. 37 , n. 1, p. 147-153, 1996

MILES, A. E. W. The Miles method of assessing age from tooth wear revisited. Journal of Archaeological Science, v. 28, n. 9, p. 973-982, 2001.

MILNER, George R.; ANDERSON, Eve; SMITH, Virginia G. Warfare in late prehistoric West-Central Illinois. American Antiquity, v. 56, n. 4, p. 581-603, 1991.

MOLNAR, Stephen. Human tooth wear, tooth function and cultural variability. American Journal of Physical Anthropology, v. 34, n. 2, p. 175-189, 1971.

MUNIZAGA, Juan R. Antropología física de los Andes del Sur. In: MEGGERS, B. (Ed.). Prehistoria Sudamericana. Washington: Taraxacum, 1992. p. 65-75.

MUNIZAGA, Juan R. Deformación craneana intencional en América. Revista Chilena de Antropología, n. 6, p. 113-147, 1987.

NAGAOKA, Tomohito; SEKI, Yuji; MORITA, Wataru; UZAWA, Kazuhiro; ALEMÁN PAREDES, Diana; MORALES CHOCANO, Daniel. A case study of a high-status human skeleton from Pacopampa in Formative Period Peru. Anatomical Science International, v. 87 , n. 4, p. 234-237, 2012.

OKUMURA, Maria Mercedes M.; EGGERS, Sabine. The people of Jabuticabeira II: reconstruction of the way of life in a Brazilian shellmound. Homo, v. 55, n. 3, p. 263-281, 2005.

OLIVEIRA, Luciana B.; SHEIHAM, Aubrey; BÖNECKER, Marcelo. Exploring the association of dental caries with social factors and nutritional status in Brazilian preschool children. European Journal of Oral Sciences, v. 116, n. 1, p. 37-43, 2008.

O'LOUGHLIN, Valerie D. Effects of different kinds of cranial deformation on the incidence of wormian bones. American Journal of Physical Anthropology, v. 123, n. 2, p. 146-155, 2004.
ORLOVE, Ben. Sticks and stones: ritual battles and play in the southern Peruvian Andes. In: POOLE, Deborah (Ed.). Unruly order: violence, power, and cultural identity in the high provinces of southern Peru. Boulder: Westview Press, 1994. p. 133-164.

PAINE, R. R.; VARGIU, R.; COPPA, A.; MORSELLI, C.; SCHNEIDER, E. E. A health assessment of high status Christian burials recovered from the Roman-Byzantine archeological site of Elaiussa Sebaste, Turkey. Homo, v. 58, n. 2, p. 173-190, 2007.

PIEPER, Klaus; DRESSLER, Simone; HEINZEL-GUTENBRUNNER, Monika; NEUHÄUSER, Anne; KRECKER, Matthias; WUNDERLICH, Klaus; JABLONSKI-MOMENI, Anahita. The influence of social status on pre-school children's eating habits, caries experience and caries prevention behavior. International Journal of Public Health, v. 57, n. 1, p. 207-215, 2012.

ROBB, John; BIGAZZI, Renzo; LAZZARINI, Luca; SCARSINI, Caterina; SONEGO Fiorenza. Social "status" and biological "status": a comparison of grave goods and skeletal indicators from Pontecagnano. American Journal of Physical Anthropology, v. 115, n. 3, p. 213-222, 2001.

ROBERTS, Charlotte; MANCHESTER, Keith. The archaeology of disease. Ithaca: Cornell University Press, 1995.

ROMERO-VARGAS, Samuel; RUIZ-SANDOVAL, José Luis; SOTOMAYOR-GONZÁLEZ, Arturo; REVUELTA-GUTIÉRREZ, Rogelio; CELIZ-LÓPEZ, Miguel Angel; GÓMEZ-AMADOR, Juan Luis; GARCÍA-GONZÁLEZ, Ulises; LÓPEZ-SERNA, Raul; GARCÍA-NAVARRO, Victor; MENDES-ROSITO, Diego; CORREACORREA, Victor, GÓMEZ-LLATA, Sergio. A look at Mayan artificial cranial deformation practices: morphological and cultural aspects. Neurosurgical Focus, v. 29, n. 6, p. E2, 2010.

ROTHSCHILD, Bruce. Extirpolation of the mythology that porotic hyperostosis is caused by iron deficiency secondary to dietary shift to maize. Advances in Anthropology, v. 2, n. 3, p. 157-160, 2012.

SAKASHITA, Reiko; INOUE, Masakazu; INOUE, Naohiko; PAN, Qifeng; ZHU, Hong. Dental disease in the Chinese Yin-Shang period with respect to relationships between citizens and slaves. American Journal of Physical Anthropology, v. 103, n. 3, p. 401-408, 1997.

SCHULTZ, Michael. Paläopathologische Diagnostik. In: KNUSSMANN, Rainer (Ed.). Anthropologie, Wesen und methoden der anthropologie. Stuttgart: Gustav Fischer Verlag, 1988. v. 1, p. 480-496.

SLAUS, Mario. Biocultural analysis of sex differences in mortality profiles and stress levels in the late medieval population from Nova Raca, Croatia. American Journal of Physical Anthropology, v. 111, n. 2, p. 193-209, 2000.

SLAUS, M.; PEĆINA-SLAUS, N.; BRKIĆ, H. Life stress on the Roman limes in continental Croatia. Homo, v. 54, n. 3, p. $240-$ 263, 2004. 
SMITH, Patricia. Diet and attrition in the Natufians. American Journal of Physical Anthropology, v. 37, n. 2, p. 233-238, 1972.

STANDEN, Vivien G.; ARRIAZA, Bernardo T. Trauma in the preceramic coastal populations of Northern Chile: violence or occupational hazards? American Journal of Physical Anthropology, v. 112, n. 2, p. 239-249, 2000

STODDER, Ann L. W.; MARTIN, Debra L. Health and disease in the southwest before and after Spanish contact. In: VERANO, John W.; UBELAKER, Douglas H. (Orgs.). Disease and demography in the Americas. Washington: Smithsonian Institution Press, 1992. p. $55-73$

STRONG, William D.; WILLEY, Gordon R.; CORBETT, John M. Archaeological studies in Peru, 1941-1942. New York: Columbia University Press, 1943.

STUART-MACADAM, Patricia. Porotic hyperostosis: a new perspective. American Journal of Physical Anthropology, v. 87, n. 1, p. 39-47, 1992

TIESLER, Vera. Head shaping and dental decoration among the ancient Maya: archeological and cultural aspects. In: ANNUAL MEETING OF THE SOCIETY OF AMERICAN ARCHAEOLOGY, 64., 1999, Chicago. Analls... Chicago: SAA, 1999. Available at: <www.mesoweb.com/features/tiesler/media/headshaping.pdf > . Accessed on: Oct. 15, 2013.

TORRES-ROUFF, Christina. Human skeletal remains from the Island of the Sun, Lake Titicaca, Bolivia. American Journal of Physical Anthropology, v. 123, suplemento 38, p. 196, 2004

TORRES-ROUFF, Christina. Shaping identity: cranial vault modification in the pre-Columbian Andes. Santa Barbara: University of California, 2003.
TORRES-ROUFF, Christina. Cranial vault modification and ethnicity in middle horizon San Pedro de Atacama, Chile. Current Anthropology, v. 43, n. 1, p. 163-190, 2002.

TORRES-ROUFF, Christina; COSTA JUNQUEIRA, María A. Interpersonal violence in prehistoric San Pedro de Atacama, Chile: behavioral implications of environmental stress. American Journal of Physical Anthropology, v. 130, n. 1, p. 60-70, 2006.

TORRES-ROUFF, Christina; YABLONSKY, Leonid T. Cranial vault modification as a cultural artifact: a comparison of the Eurasian steppes and the Andes. Homo, v. 56, n. 1, p. 1-16, 2005.

TRINKAUS, Erik. Artificial cranial deformation in the Shanidar 1 and 5 Neandertals. Current Anthropology, v. 23, n. 2, p. 198-199, 1982.

TUNG, Tiffiny A. Trauma and violence in the Wari Empire of the Peruvian Andes: warfare, raids, and ritual fights. American Journal of Physical Anthropology, v. 133, n. 3, p. 941-956, 2007.

WALKER, Phillip L. Cranial injuries as evidence of violence in prehistoric southern California. American Journal of Physical Anthropology, v. 80, n. 3, p. 313-323, 1989

WALKER, Phillip L.; COOK, Della Collins; LAMBERT, Patricia M. Skeletal evidence for child abuse: a physical anthropological perspective. Journal of Forensic Sciences, v. 42, n. 2, p. 196-207, 1997.

WALKER, Phillip L.; HEWLETT, Barry S. Dental health diet and social status among Central African foragers and farmers. American Anthropologist, v. 92, n. 2, p. 383-398, 1990.

WATSON, James T. Changes in food processing and occlusal dental wear during the early agricultural period in northwest Mexico. American Journal of Physical Anthropology, v. 135, n. 1, p. $92-$ 99, 2008.

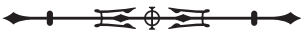

